Article

\title{
Profiting from Green Innovation: The Moderating Effect of Competitive Strategy
}

\author{
Jiawen Chen ${ }^{1}$ and Linlin Liu ${ }^{2,3, *}$ \\ 1 School of Management, Jinan University, Guangzhou 510632, China; jiawenchen@jnu.edu.cn \\ 2 School of Business Administration, South China University of Technology, Guangzhou 510651, China \\ 3 College of Business, City University of Hong Kong, Kowloon 999077, Hong Kong, China \\ * Correspondence: linlinliu5-c@my.cityu.edu.hk; Tel: +86-17620988859
}

Received: 6 November 2018; Accepted: 12 December 2018; Published: 20 December 2018

check for updates

\begin{abstract}
Despite the importance of green innovation, empirical evidence on its relationship with firm performance is mixed. This study endeavors to address this inconsistency in the evidence by investigating the value-capturing role of competitive strategy. It argues that firms tend to choose appropriate a competitive strategy to maximize performance of green innovation, especially in highly competitive contexts. We collected data from 195 firms in China. Our results suggest that the performance implications of green innovation (including green product innovation and green process innovation) are moderated by competitive strategies (including differentiation strategy and cost-leadership strategy), and these moderating effects are more prominent when competitive intensity is high. The findings of this study enrich theoretical understanding both of green innovation and of competitive strategy and have practical implications for green innovation management.
\end{abstract}

Keywords: green innovation; firm competitiveness; competitive strategy

\section{Introduction}

Green innovation involves redefining and exploring new, environmentally-friendly elements in product development and production [1,2]. It entails substantial resource investment, and helps firms meet external public expectations and requirements with regard to environmentalism [3-5]. A competitive perspective suggests that there is a close link between competition and innovation, in which a firms' innovation activities are driven by competition in the marketplace [6-8]. However, green innovation, including green product innovation and green process innovation [9], is a proactive action that aims to address increasing pressure to focus upon environmental sustainability rather than market competition [10]. Given that many firms have initiated green innovation programs [11], it is important to investigate how firm performance is affected by green innovation.

Given the importance of green innovation, there are ambiguities on its performance implications in previous studies $[2,10]$. Some studies found that green innovation enhances firms' competitiveness. Firms engaging in green innovation can gain greater social support from external and internal stakeholders, as well as access to valuable resources $[9,11]$. But other studies found that green innovation has nonsignificant or even negative effects on firms' performance, which tend to suggest that green innovation may be irrelevant to firms' competitiveness [12,13]. These mixed findings thus make it desirable to further explore the question of how firms can profit from their efforts in green innovation, so that we can thereby achieve a more nuanced understanding of its implications for performance.

While green innovation can create value for firms in a competitive market, firms need to have an appropriate strategy in place if they are to capture such potential value [14,15]. In accordance with the implications of the literature on competitive strategy, firms' competitive strategies can be 
expected to shape the ways they leverage and harness the valuable resources obtained from green innovation [16,17]; consequently, performance implications of green innovation may be dependent on a firm's competitive strategy. Therefore, to reveal the complexity of the association between green innovation and firm performance, the complementary role of business strategy in accomplishing the performance effects of green innovation must be taken into consideration. However, current research on green innovation has not explicitly examined the complementary effect between green innovation and business strategy.

In an endeavor to fill the research gap noted above, this study investigates how firms' competitive strategies can moderate the relationship between green innovation and firm performance. Differentiation and cost-leadership strategies are two basic types of competitive strategy which have been widely highlighted in previous literature $[18,19]$. It has been suggested that competitive strategy can either enable firms to derive profit from green product innovation and green process innovation, or hinder them in doing so $[1,11]$. Therefore, this study investigates the contingencies of both differentiation and cost-leadership strategies on the link between green product innovation and firm performance and between green process innovation and firm performance. Moreover, research suggests that the potential competitiveness obtained from green innovation is more likely to be imitated and surpassed as competition in the market increases [20,21]. Therefore, a high level of competitive intensity imposes additional requirements on capturing value from green innovation [22]. This study thus also examines how competitive intensity shapes the moderating effects of business strategy. By examining this aspect, we can further identify and elaborate the critical role of both differentiation and cost-leadership strategies in green innovation. Our proposed model is shown in Figure 1.

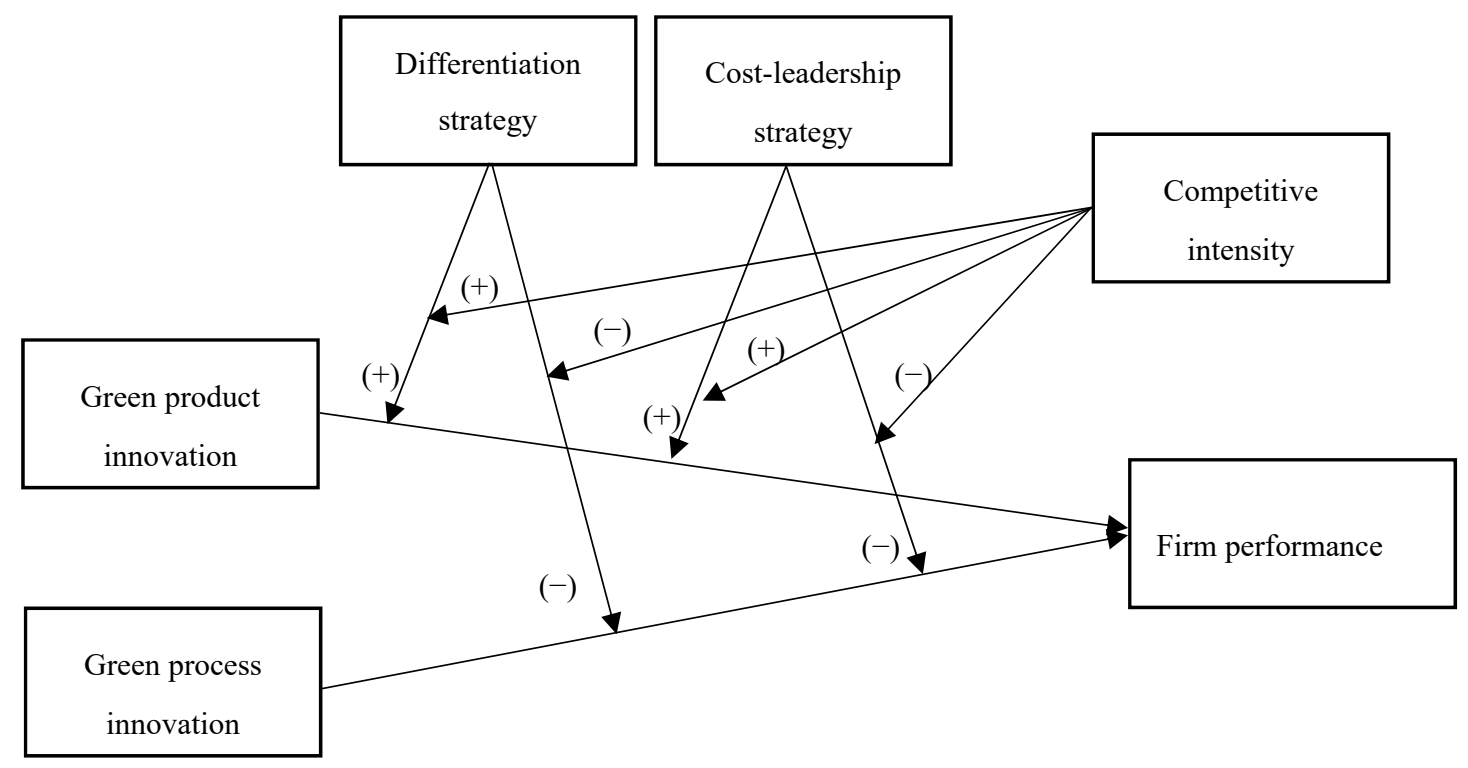

Figure 1. Research model of this study.

Our findings make contributions to current research on green innovation and competitive strategy in two important ways. First, by elucidating the contingency of competitive strategy, this study provides a potential perspective to explain the existing inconsistent research conclusions on the green innovation-firm performance linkage, thus enriching our understanding of the plausible ways of maximizing performance implications of green innovation. Second, several scholars have appealed for more research on exploring the value-capturing potential of green innovation as determined by competitive strategy $[23,24]$. This study responds by investigating how competitive strategy facilitates firms' profiting from green innovation in different competitive contexts. In addition, our study have practical implications for managers with regard to the effective management of green innovation within a competitive environment. 


\section{Literature Review and Hypotheses}

\subsection{Green Innovation and Firm Performance}

Firm performance reflects the extent to which a firm successfully achieves its goal, which is closely linked to its competitive advantage in the marketplace [25]. Firms enhance and sustain their performance by engaging in activities of value creation and capture [26]. Literature on strategic management has highlighted the determinants of both firm competitive strategies and market structures on firm performance [27,28], as well as nonmarket strategies such as green innovation [29].

Due to increasing environmentalist pressure from governments and consumers, firms actively engage in green innovation for the sake of making a contribution to sustainable development $[4,5,30]$. Green innovation comprises both green product and green process innovation. It denotes activities that modify product design on one hand, and those that refine production on the other, both of which aim to mitigate any negative impacts on the environment and realize environmentalist value [1,2,12]. Green product innovation refers to the introduction of a new product or service that is environmentally friendly $[1,20]$. Green process innovation is the proactive adaption of production processes by using green technologies and designs that diminsh hazards on the ecosystem [1,30].

Given the importance of green innovation in environmental sustainability [31], several scholars have explored its performance implications. Some propose and find a positive effect of green innovation on firm performance [9,32]. For example, Chiou et al. [33] suggest that green innovation can enhance firms' environmental performance and improve competitive advantages by increasing support from stakeholders. Chang [11] indicates that green innovation promote firms' market performance because green innovation can enhance a product's value in the minds of consumers and offset the opportunity costs of environmental investment. Ge et al. [34] also indicate that green innovation can generate dynamic capability for firms, and thus, improve sustainable competitiveness. Based on an international survey of wineries, Leenders and Chandar found that wineries' green innovation efforts have direct and positive effects on their business performance [35]. However, other studies find patterns for the relationship between green innovation and firm performance that are not consistent with those conclusions. For instance, Caracuel and Mandojana [13] find that green innovative firms do not achieve or experience improved profitability. Liu [9] suggests that green innovation can lead to increased costs and observes that green innovation is negatively associated with financial performance. Based on a survey of a sample of German firms, Ghisetti and Rennings also find that green innovation aimed at reducing external negativity leads to reduced financial performance due to the overwhelming cost burden [36]. Chen and Chang [37] show an inverted U-shaped linkage between green innovation and firm competitiveness and suggest that corporate competitive advantage will be compromised as green innovation increases to a high level. Such inconclusive empirical findings imply that a more nuanced understanding of the green innovation-firm performance nexus is required.

A few scholars have started to draw on a contingent approach to explain the varied and seemingly contradictory performance effects of green innovation. For instance, Chan et al. [38] found that environmental dynamism moderates the green innovation-firm performance linkage. Based on observations of Spanish agricultural firms, Martinez-del-Rio et al. [39] showed that green innovation has greater effects on firm performance when munificence is high. Leonidou et al. [40] also suggested that external forces such as regulatory intensity and public concern will influence the positive link between green management and competitive advantage. However, since the external forces in the environment are beyond the control of particular firms, current research on the contingencies of environmental factors provides limited strategic advice for firms to capture the economic benefits of green innovation in a proactive way. Therefore, uncertainty persists about the causes of mixed findings regarding the performance implications of green innovation, and a more nuanced understanding of value capture from green innovation is still needed.

This study aims to remove the uncertainty by articulating the value capturing role of business strategy in green innovation. Prior studies on competitive strategy suggest that while innovation can 
be translated into superior performance, firms should craft and implement an appropriate strategy to realize the potential value of that innovation $[16,41]$. Firms' competitive strategies may determine the extent to which firms can reap the benefits from the investment in green innovation. As a competitive strategy is at the discretion of firms' managers [42], exploring how competitive strategies moderate the green innovation-firm performance linkage enables us to better explain firms' value capture from green innovation.

\subsection{Business Strategy}

As suggested by Porter's framework of generic competitive strategy [18], an advantageous position in the market can result from either differentiation or cost-leadership; thus, firms which adopt differentiation and cost-leadership strategies can gain competitive advantages [19,43]. A differentiation strategy aims at offering products or services that can be perceived as distinctive and valuable for consumers $[18,44]$. Differentiation can be achieved in three way: vertical differentiation, in which consumers rank one product over another generally; horizontal differentiation, in which only some consumers prefer a product to other similar products based on the preference of taste; mixed differentiation, in which consumers rank product based on both quality and taste $[10,45]$. Differentiation strategy enables firms to cultivate and maintain customer loyalty and to charge premium prices that compensate for the additional costs incurred in pursuit of differentiation [46]. In contrast, a cost-leadership strategy focuses on providing customers with products or services at a lower price than their competitors [18,47]. Firms adopt cost-leadership strategies to reduce costs by means of scale economies, cost control, or efficient production [18]. A cost-leadership strategy not only helps firms gain a competitive advantage through delivering the same or similar offerings at lower but more profitable prices, it also helps them expand market share [48,49].

Business strategies are argued to be critical in improving and sustaining firms' competitiveness, and scholars have empirically verified the performance implications of these two competitive strategies $[40,50]$. Moreover, some studies articulated the significant value of differentiation and cost-leadership strategies from a resource-based view of firms. Different types of competitive strategies are associated with distinct sets of resources and capabilities [51], and the value of resources and capabilities can be realized though particular business strategies [52,53]. Competitive strategy is thus a non-negligible factor that helps firms capture value from green innovation [23]. To enhance its competitive advantage, a firm needs to adopt a proactive strategy for green innovation which is capable of successfully increasing environmental protection, while at the same time improving performance $[54,55]$. Moreover, green innovation is not naturally or necessarily provided with an appropriate competitive strategy. Green innovation may be simply a firm's response to environmental pressure from certain stakeholders, rather than to strategic considerations of competitiveness $[3,5,56]$. It is therefore important to identify how far firms rely on competitive strategy in capturing the value of green innovation.

\subsection{Hypotheses}

\subsubsection{Differentiation Strategy}

Firms oriented toward differentiation are dedicated to offering products that are distinguished from those of their competitors by consumers [18]. Green product innovation requires product design and development to incorporate new features that take environmental concerns into account [20], and thus, it supports the firm's differentiation strategy. Green process innovation, in contrast, entails investment in cost reduction and efficiency enhancement [30], which creates a tension between it and differentiation strategy. As a result, differentiation strategy will shape the performance implications for different types of green innovation in different ways.

We argue that a positive relationship between green product innovation and firm performance is enhanced by differentiation strategy. First, firms engaging in introducing new green products 
will incorporate green elements in their product design; this satisfies customer needs regarding environmental sustainability. Thus, green product innovation can be effective in promoting customer loyalty and rendering a firm's product unique compared to its competitors [57]. Differentiation strategy focuses on distinct product design and accords very well with the potential performance contribution of green product innovation [14]. Hence, we argue that for firms adopting a differentiation strategy, green product innovation will be more profitable and valuable. Second, to harness the benefits of green product innovation, firms should take actions to communicate to the market the environmental advantages generated by green product innovation [58]. Since differentiation strategy focuses on distinguishing firms from their rivals, it thereby facilitates firms positioning themselves clearly in a competitive market by introducing new green products [59]. Furthermore, differentiation strategy is targeted at customer loyalty, and helps firms enter new market segments, expand their product portfolio, and acquire higher premium benefits [44]. Consequently, differentiators are more capable of taking profit from green product innovation and enjoy greater economic benefits from green product innovation.

A differentiation strategy may also induce higher costs of inputs for the innovative green products [60], and potentially reduce a firm's profitability. We argue that the induced costs of inputs can be compensated for by the higher sale of green products if a firm adopts a differentiation strategy. Consumers are more likely to purchase a firm's green product at a higher price premium when the firm successfully establishes and communicates their green image through a differentiation strategy $[30,61]$. Therefore, the benefits of green product innovation may surpass its costs for differentiators. This leads to the following hypothesis:

Hypothesis 1 (H1). Differentiation strategy positively moderates the relationship between green product innovation and firm performance.

We also argue that differentiation strategy will negatively moderate the green process innovation-firm performance association. First, the mismatch between green process innovation and differentiation strategy may generate resource tensions that undermine firm performance. Green process innovation helps to reduce costs by using refined and upgraded green technology [2]. But the experimentation with and introduction of new product features in accordance with differentiation strategy will incur additional costs [62]. As a result, tensions between differentiation strategy and green process innovation arise and jeopardize firms' competitiveness. Second, firms adopting a differentiation strategy find it hard to take advantage of the superior efficiency yielded by green process innovation. Previous studies suggest that pollution is inefficient for resource consumption and utilization and generates higher costs in value chain management [63]. Green process innovation can mitigate the negative impacts of pollution and reduce costs and inefficiency, which would thus provide firms with market advantages. Differentiation strategy directs firms' strategic attention to product design, rather than to establishing and sustaining the advantage of lower cost and higher efficiency. Thus, firms oriented toward differentiation may find it difficult to improve profitability through green process innovation.

A differentiation strategy may potentially enhance the performance implications of green process innovation, because differentiators can advertise its green production technologies and acquire a price premium [64]. However, we argue that the increased benefits cannot cover the costs generated in the implementation of a differentiation strategy. Advertising of green production technologies in differentiation strategies facilitates imitation of focal firms' competitors and may erode their technological advantages [65]. Therefore, the benefits of differentiation strategies in green process innovation are rather limited. In sum, we hypothesize that:

Hypothesis 2 (H2). Differentiation strategy negatively moderates the relationship between green process innovation and firm performance. 


\subsubsection{Cost-Leadership Strategy}

Cost-leadership strategy generates competitive advantage through superiority in resource efficiency and cost reduction [18]. Green product innovation incurs high experimentation costs, which conflicts with any cost-leadership strategy, but green process innovation lowers resource consumption and improves efficiency, which matches the focus of cost-leadership strategy [11]. Consequently, cost-leadership strategy may influence how firms take advantage of green product innovation differently from how they take advantage of green process innovation.

We expect that a cost-leadership strategy negatively moderates the green product innovation-firm performance association. First, green product innovation requires firms to commit substantial resources, and is accompanied with high uncertainty [66]. Firms usually need to bear high costs when introducing a new product that mitigates environmental concerns (for example, the costs incurred by potential failure to incorporate green elements in the product design). Cost-leadership strategy focuses on reducing product costs by refining and upgrading existing technological knowledge in production and the relevant market segment [22]. Hence, firms pursuing a cost-leadership strategy may derive lower profits from green product innovation, due to the conflict between their cost-leadership strategy and the costs of green product innovation. Second, cost-leadership strategy inhibits value capturing from green product innovation. To secure the benefits of green product innovation, firms leverage and highlight the ecological features of green products in a competitive market [23]. But cost-leadership strategy focuses on actions pertaining to cost reduction rather than advertising the novelty of new products or entering new market segments [67]. The profits gained from green product innovation dwindle with the adoption of a cost-leadership strategy. Therefore, if firms overinvest in green product innovation while adopting a cost leadership strategy, green product innovation turns out to be cost ineffective.

A cost-leadership may help absorb the incurred costs of inputs during the product innovation [68] in a way that promotes a firm's performance. However, such benefits of cost-leadership strategies are difficult to realize. Green product innovation requires novel inputs, which are new to firms. Cost-leaders tend to reduce cost incrementally by replicating the best existing routines and processes within firms [69]. Therefore, a cost-leadership strategy has a limited capability to absorb the costs during the development and introduction of new green innovations. In sum, we expect that:

Hypothesis 3 (H3). Cost-leadership strategy negatively moderates the relationship between green product innovation and firm performance.

In contrast, cost-leadership strategy can be argued to positively moderate the relationship between green process innovation and firm performance. First, green process innovation can minimize production costs and enhance resource efficiency [69]. Firms engaging in green process innovation may adopt a cost-leadership strategy to take low-cost advantage in a concerted way [1]. Thus, green process innovation is supported by a cost-leadership strategy and has more pronounced performance implications for firms aiming to be cost-leaders in the market. Second, a cost-leadership strategy enables firms to protect the profits of green process innovation. Firms can capture value from green process innovation by creating unique patterns of manufacturing that hinder rivals' learning $[15,70]$. Cost-leadership strategy aims to obtain and sustain low-cost advantage over rivals by offering products in a particularly efficient way [71], thereby making it easier for firms to profit from green process innovation. Consequently, firms achieve greater competitiveness by green process innovation and hold a stronger green process innovation-firm performance linkage.

A cost-leadership strategy may also potentially reduce the benefits gained from green process innovation, since cost-leaders engage in fewer activities of communicating their green images in the market [30]. We suggest that firms which adopt cost-leadership strategies can gain support from stakeholders by achieving certification by third-party auditors [72]. For example, Terlaak and King [73] found that ISO 14001 can be a signal of environmental responsibility which helps firms benefit from their improved green production processes. Therefore, we expect that: 
Hypothesis 4 (H4). Cost-leadership strategy positively moderates the relationship between green process innovation and firm performance.

\subsubsection{Competitive Intensity}

The above arguments suggest that competitive strategy is critical in capturing value from green innovation. To identify the underlying mechanisms, we further articulate and examine the influence of competitive intensity in the moderation of competitive strategies. Competitive intensity refers to the degree of competition a firm encounters in the industries which it is involved [74-76]. Earlier studies suggest that firms' activities of value capturing become critical when competition is intense [17,77], because a firms' product and process may be more likely to be imitated or surpassed by competitors [15]. Further, taking advantage of green management through the adoption of an appropriate strategy is helpful for firms to fend off market competition [6,21,22]. Accordingly, the value capturing role of business strategy should be more prominent for firms facing high competitive intensity.

Regarding the relationship between green innovation and firm performance, the contingent role of differentiation strategy will be more prominent as competitive intensity increases. First, differentiation strategy make it easier for a firm to profit from green product innovation expeditiously, especially when competitive intensity is high. The time period in which firms maintain a competitive advantage over competitors will be curtailed by competitive intensity, and this phenomenon thus requires firms to capture the value of green product innovation more rapidly [58,77]. Differentiation strategy helps firms harness the benefits of introducing new green products by distinguishing themselves from their competitors, cultivating customer loyalty, and expanding generic market segments [78]. Thus, differentiation strategy becomes a more important and efficient means for firms to profit from green product innovation in a situation of fierce competition. Second, the tension between differentiation strategy and green process innovation becomes hazardous in a highly competitive market. Green process innovation requires firms to invest resources in enhancing manufacturing and production by utilizing green technology and upgrading green capability [15,79]. Differentiation strategy directs firms' resource allocation toward introducing distinctive products into the market, and it is thus incapable of realizing the low-cost potentials of green process innovation [19]. Increased competitive intensity further amplifies the negative impact of such a lack of capability, since firms need to defend the advantageous position, they gain from green process innovation in order to overcome intense competition. Therefore, differentiators will find it harder to protect the return on green process innovation when competition is intense.

In sum, in highly-competitive contexts, differentiation strategy is more instrumental in capturing the value of green product innovation, but at the same time, it is more pronounced in hindering the obtention of benefits from green process innovation. Therefore,

Hypothesis 5a (H5a). Competitive intensity will strengthen the positive moderating effect of differentiation strategy on the relationship between green product innovation and firm performance.

Hypothesis $\mathbf{5 b} \mathbf{b} \mathbf{H} \mathbf{b})$. Competitive intensity will strengthen the negative moderating effect of differentiation strategy on the relationship between green process innovation and firm performance.

Regarding the moderating effects of cost-leadership strategy, we expect that it will be more salient in context of high competitive intensity. First, cost-leadership will further hinder a firm's ability to capture value from green product innovation as competitive intensity increases. Leveraging the new knowledge to profit from green product innovation helps firms cope with pressures from intense competition [20]. But a cost-leadership strategy cannot support leveraging new knowledge from green product innovation $[44,80]$, and thus, becomes even more ineffective in capturing benefits from green product innovation when competition is intense. Second, the role of a cost-leadership strategy in enabling firms to derive benefits from green process innovation will be more profound if 
the market is highly competitive. A cost-leadership strategy enhances firms' competitive advantages through green process innovation, since it enable firms to offer products in more efficient ways and establish distinctive manufacturing patterns that isolate them from imitation by rivals [78]. These methods become even more efficient as competitive intensity increases, because they empower firms to safeguard advantageous positions and defend competitive actions in the market [81]. Hence, a cost-leadership strategy is a more pronounced factor in achieving the performance implications of green process innovation when firms encounter fiercer competition. Accordingly, this leads to the following hypotheses:

Hypothesis 6a (H6a). Competitive intensity will strengthen the negative moderating effect of cost leadership strategy on the relationship between green product innovation and firm performance.

Hypothesis $\mathbf{6 b} \mathbf{( H 6 b )}$. Competitive intensity will strengthen the positive moderating effect of cost leadership strategy on the relationship between green process innovation and firm performance.

\section{Methods}

\subsection{Sample}

The hypothesized relationships were tested with primary data collected in a survey of Chinese firms. Based on the previous study and in-depth interviews, we developed our questionnaire in English. To ensure accuracy, two researchers translated the original questionnaire into Chinese, and then two other researchers back-translated it into English. Next, we conducted a pilot study to ensure the interpretability of our questionnaire. Twenty senior managers were invited to review our Chinese version and provide feedback on the soundness and completeness of related items. We identified three regions of mainland China according to their development levels: Guangdong, Shandong, and Shaanxi. We drew a random sample of 600 firms from the manufacturing sectors using provincial government directories. To increase the valid response rate to our survey, telephone inquiries with executives or owners of the sampled firms were conducted to ask for their agreement for participation. After making an appointment, interviewers visited and conducted face-to-face interviews with managers in their offices. The whole data collection process lasted 9 months, from June 2017 to February 2018.

We collected data from two managers in each firm in order to limit common method bias in our study. Finally, 195 validated responses were received. The profile of our sampled firms is presented in Table 1 . On average, the sampled firms had been in business for about 11 years and had more than 110 employees. We used $t$-tests to check for the potential problem of nonresponse bias. We compared responding and nonresponding firms by some major attributes such as firm age, size, etc. The results of that comparison showed that all the statistics are nonsignificant, which suggests that the nonresponse bias was not a severe problem in our study.

\subsection{Measurement}

Table 2 presents the measurement items and the results of our validity assessment. The main variables are measured by multiple items on a seven-point Likert scale, which ranges from 1 (strongly disagree) to 7 (strongly agree).

Following prior studies by Chen [1] and Chang [11], both green product innovation and green process innovation were measured with four items. Items related to green product innovation were adapted to assess the environmental friendliness in product development or design. Items related to green process innovation were adapted to describe environmental improvement in the manufacturing process such as reducing emissions and consumption. Firm performance was operationalized by subjective measures, which have been shown to be more effective and reliable in China $[82,83]$. We used three items with respect to firms' return on sales, assets, and investment. 
Table 1. Profile of sampled firms.

\begin{tabular}{|c|c|c|}
\hline Sample Characteristics & Frequency & Percentage \\
\hline \multicolumn{3}{|c|}{ Sector } \\
\hline Electronic component & 41 & $21.0 \%$ \\
\hline Chemicals & 35 & $17.9 \%$ \\
\hline Metal products & 29 & $14.9 \%$ \\
\hline Information hardware & 28 & $14.3 \%$ \\
\hline New energy and new materials & 23 & $11.8 \%$ \\
\hline Other & 39 & $20.0 \%$ \\
\hline \multicolumn{3}{|c|}{ Geographic Location } \\
\hline Guangdong & 76 & $39.0 \%$ \\
\hline Shandong & 64 & $32.8 \%$ \\
\hline Shaanxi & 55 & $28.2 \%$ \\
\hline \multicolumn{3}{|c|}{ Firm Age (Years) } \\
\hline$<10$ & 86 & $44.1 \%$ \\
\hline $10-19$ & 95 & $48.7 \%$ \\
\hline$\geq 20$ & 14 & $7.2 \%$ \\
\hline \multicolumn{3}{|c|}{ Firm Size (Number of Employees) } \\
\hline$<50$ & 41 & $21.0 \%$ \\
\hline $50-100$ & 48 & $24.6 \%$ \\
\hline $100-299$ & 75 & $38.5 \%$ \\
\hline $300-499$ & 31 & $15.9 \%$ \\
\hline \multicolumn{3}{|c|}{ Annual Sales (in Millions of RMB) } \\
\hline$<10$ & 86 & $44.1 \%$ \\
\hline $10-49$ & 81 & $41.5 \%$ \\
\hline$\geq 50$ & 28 & $14.4 \%$ \\
\hline
\end{tabular}

Table 2. Measurement scales.

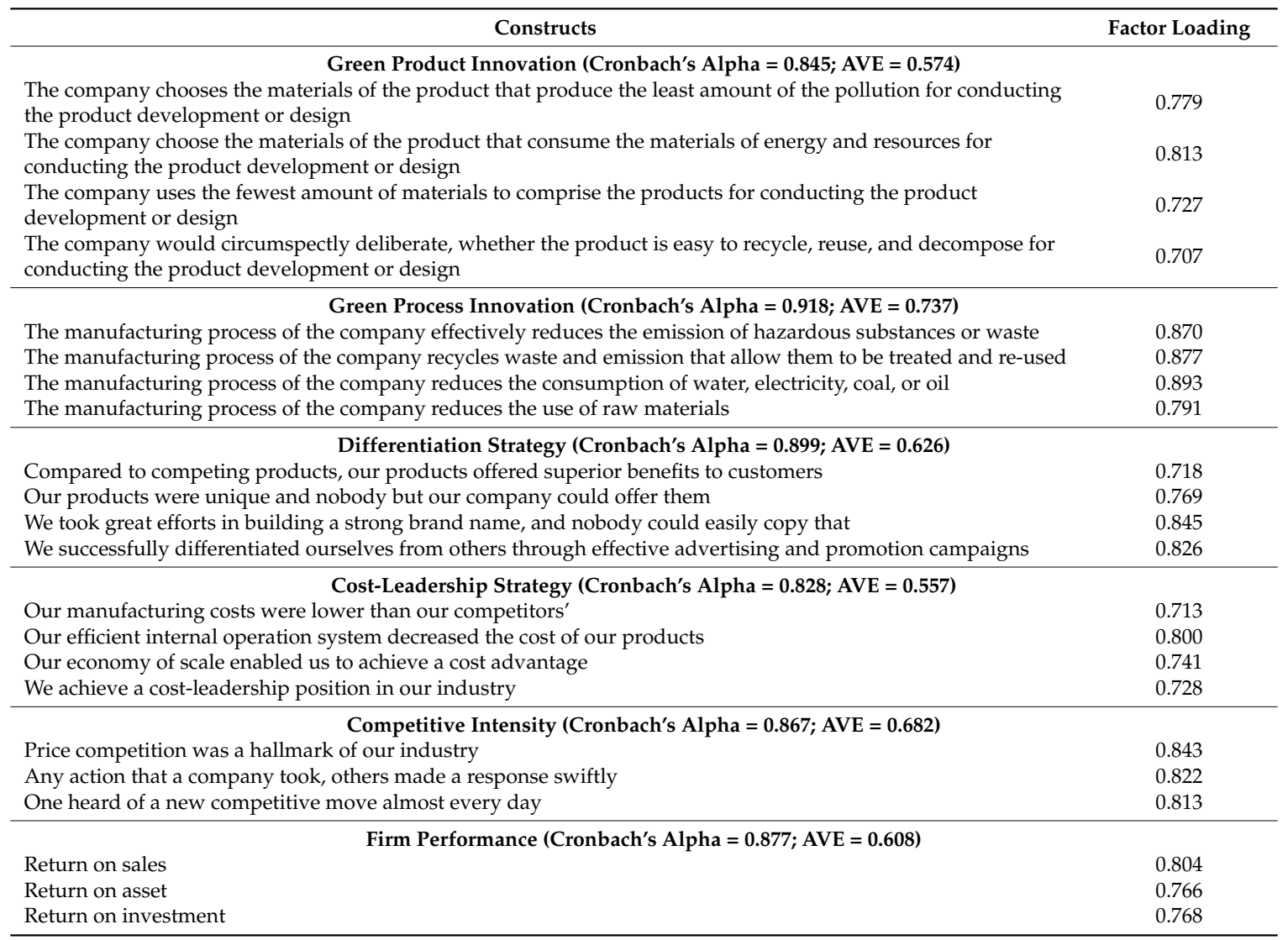


Measures of competitive strategy were adapted from Li and Li [19]. They have been demonstrated as being reasonably reliable and valid in the Chinese context $[80,84]$. Four items were used to operationalize differentiation strategy, reflecting the extent to which firms differentiate themselves from competitors in products and services. Another four items were adopted to measure cost-leadership strategy, assessing the cost reduction in manufacturing. Our measures capture a firm's overall orientation toward differentiation and cost-leadership, rather than particular dimensions of strategies such as pricing and operating costs. We do so because these strategic dimensions vary across firm divisions, and the overall orientation can provide a broad description of a firms' desired market position [85]. Drawing on Jaworski and Kohli [74] and Zhou [77], we measured competitive intensity with three items, which describe the extent of industry competition.

Five variables were controlled for. Firm age was measured by the logarithm of the number of years since the firm was started. Firm size was measured by the logarithm of the total number of employees. Export orientation was measured by surveying whether the company's market scope was local, national, or global, and was coded as 1, 2, and 3 respectively. High-tech was measured by a dummy variable which was coded as 1 for high-tech firms and 0 otherwise. Region was a dummy variable that measures whether the company is located in eastern provinces in China.

\subsection{Reliability and Validity}

The construct reliability was tested by Cronbach's alpha. As shown in Table 2, all alpha values exceeded 0.7, which indicates that the reliability of each construct was reasonably satisfied [86]. We evaluated convergent and discriminant validity with factor loadings and average variance extracted (AVE). In Table 2, all factor loadings of the main constructs were above 0.7, and AVEs were above 0.5. A confirmatory factor analysis (CFA) also indicated an acceptable model fit $\left(\chi^{2} / \mathrm{df}=1.55, \mathrm{GFI}=0.94\right.$, $\mathrm{CFI}=0.98, \mathrm{IFI}=0.97, \mathrm{RMSEA}=0.041)$. We evaluated discriminant validity by assessing whether the squared roots of AVE of each variable were higher than the correlations between the variable and the other variables. As shown in Table 3, results indicated a satisfied discriminant validity. 
Table 3. Means, standard deviations, correlations, and AVEs.

\begin{tabular}{|c|c|c|c|c|c|c|c|c|c|c|c|}
\hline Variables & 1 & 2 & 3 & 4 & 5 & 6 & 7 & 8 & 9 & 10 & 11 \\
\hline 1. Firm age & 1 & & & & & & & & & & \\
\hline 2. Firm size & $0.35 *$ & 1 & & & & & & & & & \\
\hline 3. Export orientation & $0.17 * *$ & 0.10 & 1 & & & & & & & & \\
\hline 5. Region & $0.18^{* *}$ & 0.04 & 0.05 & 0.05 & 1 & & & & & & \\
\hline 6. Green product innovation & $0.15^{* *}$ & -0.06 & 0.03 & 0.06 & $0.17 * *$ & 0.757 & & & & & \\
\hline 7. Green process innovation & $0.12 *$ & $-0.09 *$ & $0.20^{* *}$ & 0.02 & $0.21^{* *}$ & $0.22 * *$ & 0.86 & & & & \\
\hline 8. Differentiation strategy & -0.06 & $-0.14^{* *}$ & $0.15^{* *}$ & $0.12 *$ & $0.16^{* *}$ & 0.24 ** & $0.29^{* *}$ & 0.79 & & & \\
\hline 10. Competitive intensity & 0.13 * & -0.02 & $0.15^{* *}$ & 0.05 & -0.08 & $0.33^{* *}$ & $0.33^{* *}$ & $0.25^{* *}$ & $0.28^{* *}$ & 0.83 & \\
\hline 11. Firm performance & 0.03 & 0.05 & -0.01 & $0.18^{* *}$ & $0.17^{* *}$ & $0.17^{* *}$ & $0.16^{* *}$ & $0.27^{* *}$ & 0.22 ** & -0.07 & 0.78 \\
\hline Mean & 2.34 & 12.03 & 1.45 & 0.38 & 0.63 & 4.28 & 4.09 & 4.79 & 4.93 & 4.48 & 3.69 \\
\hline Standard deviation & 1.07 & 11.54 & 0.57 & 0.39 & 0.83 & 1.22 & 1.03 & 1.14 & 1.21 & 1.04 & 0.98 \\
\hline
\end{tabular}

Note: 1. Off-diagonal elements are the correlational variables. 2. Diagonal elements are square roots of the AVE values.3. ${ }^{*} p<0.05 ;{ }^{* *} p<0.01$. 


\section{Results}

The means, standard deviations, correlations of variables in the study are presented in Table 3. We used the regression method to test our hypotheses. We used the Durbin-Watson test to examine the independence of residuals. The DW value is 1.98 , which suggests that interdependence of residuals is not severe. As shown in the histogram of regression standardized residual and P-P plot, our models does not violate the assumption that residuals should be normally distributed (Please see Figures A1 and $\mathrm{A} 2$ in the Appendix A). We also drew the scatter plot between residuals and predicted firm performance, which shows no obvious problem of heteroscedasticity (See Figure A3 in the Appendix A). Finally, we computed the variance inflation factors (VIFs) for all variables; the largest VIF is 1.45, suggesting that the multicollinearity problem is not a serious concern. All variables were mean-centered before being entered into models in order to mitigate the potential of multicollinearity occurring.

Table 4 presents the results of hierarchical regression models in this study. Model 1 reports baseline specification with control variables only. As shown in Model 2, firm performance is positively related to both green product innovation and green process innovation, which supports the assertion that green innovation can provide firms with competitive advantages in the market. For H1 and $\mathrm{H} 2$, we considered the moderating effects of differentiation strategy. Model 3 reports that the moderating effect of differentiation strategy on the green product innovation-firm performance linkage is significantly positive $(\beta=0.14, p<0.01)$, but the moderating effect of differentiation strategy on the relationship between green process innovation and firm performance is significantly negative $(\beta=-0.27, p<0.01)$. These findings support $\mathrm{H} 1$ and $\mathrm{H} 2$. For $\mathrm{H} 3$ and $\mathrm{H} 4$, we considered the influences of cost-leadership strategy. In Model 4, we found that cost-leadership strategy weaken the positive green product innovation-firm performance relationship $(\beta=-0.18, p<0.001)$ while enhancing the positive association between process innovation and firm performance $(\beta=0.21$, $p<0.001)$. These findings are consistent with $\mathrm{H} 3$ and H4. To further verify our results, we plotted these moderating effects in support of these hypotheses (see Figures 2 and 3).

Table 4. Results of regression analysis.

\begin{tabular}{|c|c|c|c|c|c|c|}
\hline Variables & Model 1 & Model 2 & Model 3 & Model 4 & Model 5 & Model 6 \\
\hline Firm age & 0.08 & 0.09 & 0.09 & 0.08 & 0.09 & 0.08 \\
\hline Firm size & 0.04 & 0.03 & 0.07 & 0.02 & 0.06 & 0.02 \\
\hline Export orientation & -0.08 & -0.08 & -0.11 & -0.10 & -0.14 & -0.13 \\
\hline High-tech & $0.21 * * *$ & $0.22 * * *$ & $0.23 * * *$ & $0.22 * * *$ & $0.26^{* * *}$ & $0.28^{* * *}$ \\
\hline Region & $0.19 * *$ & $0.17 * *$ & $0.18^{* * *}$ & $0.19 * *$ & $0.21 * *$ & $0.22 * *$ \\
\hline Green product innovation (product) & & $0.10 *$ & $0.11 *$ & $0.14 *$ & 0.16 & 0.17 \\
\hline Green process innovation (process) & & $0.07 *$ & $0.09 *$ & $0.12 *$ & $0.14 *$ & $0.15 *$ \\
\hline Differentiation strategy (DS) & & & $0.24^{* * *}$ & & $0.26^{* * *}$ & \\
\hline Cost-leadership strategy (CS) & & & & $0.20 * * *$ & & $0.23 * * *$ \\
\hline Product $\times$ DS & & & $0.14^{* *}$ & & $0.16^{* *}$ & \\
\hline Process $\times$ DS & & & $-0.27^{* *}$ & & $-0.21^{* *}$ & \\
\hline Product $\times$ CS & & & & $-0.18^{* * *}$ & & $-0.20 * * *$ \\
\hline Process $\times$ CS & & & & $0.21 * * *$ & & $0.24 * * *$ \\
\hline Competitive intensity (CI) & & & & & -0.02 & 0.01 \\
\hline Product $\times$ CI & & & & & $0.19^{* *}$ & $0.22 * *$ \\
\hline Process $\times \mathrm{CI}$ & & & & & $0.17 * *$ & $0.20 * *$ \\
\hline $\mathrm{DS} \times \mathrm{CI}$ & & & & & $0.12 * *$ & \\
\hline $\mathrm{CS} \times \mathrm{CI}$ & & & & & & $-0.21 * *$ \\
\hline Product $\times \mathrm{DS} \times \mathrm{CI}$ & & & & & $0.09 *$ & \\
\hline Process $\times$ DS $\times \mathrm{CI}$ & & & & & $-0.11 *$ & \\
\hline Product $\times \mathrm{CS} \times \mathrm{CI}$ & & & & & & $-0.24 * * *$ \\
\hline Process $\times \mathrm{CS} \times \mathrm{CI}$ & & & & & & $0.18^{* *}$ \\
\hline $\mathrm{R}^{*}$ & 0.10 & 0.18 & 0.24 & 0.20 & 0.29 & 0.25 \\
\hline Adjusted R* & 0.08 & 0.14 & 0.21 & 0.16 & 0.23 & 0.19 \\
\hline F-value & $1.96^{* * *}$ & $4.15^{* * *}$ & $5.01 * * *$ & $4.53 * * *$ & $4.81 * * *$ & $4.30 * * *$ \\
\hline
\end{tabular}



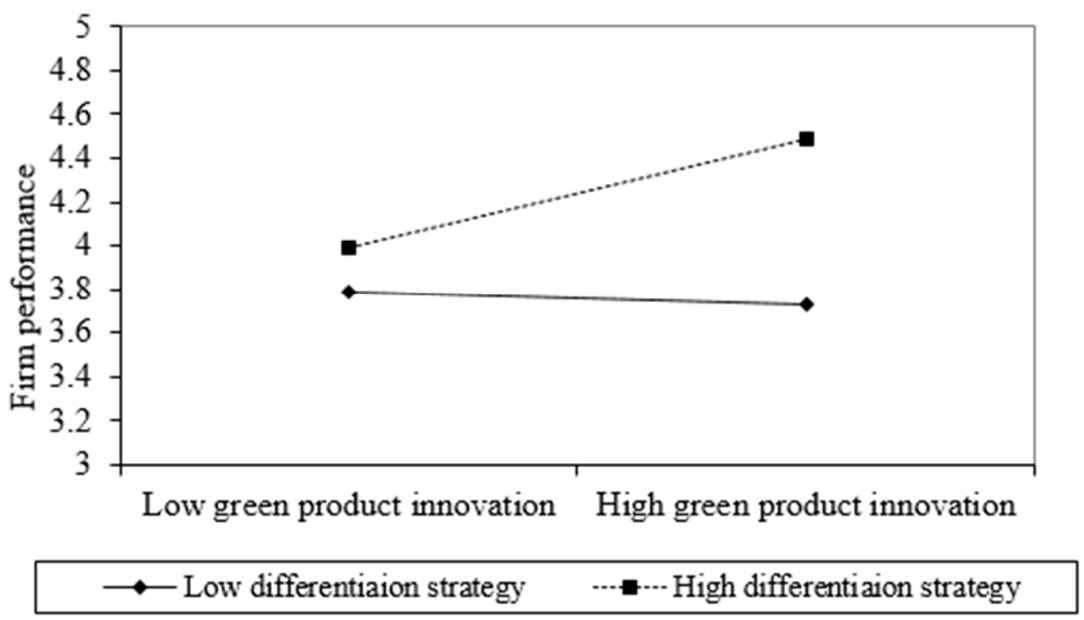

(a)

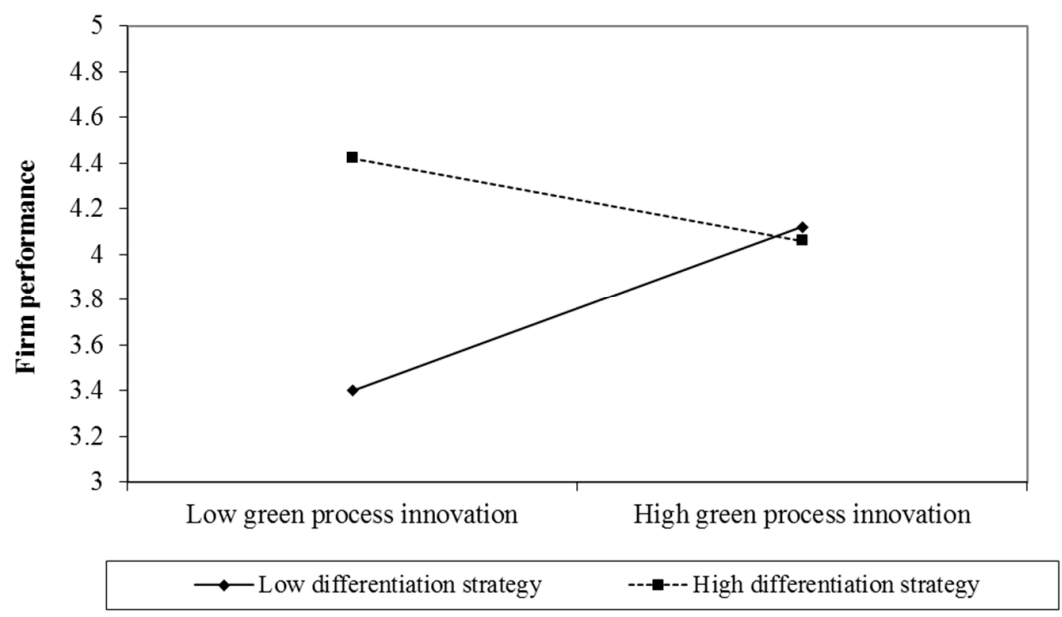

(b)

Figure 2. (a) Differentiation strategy, green product innovation, and firm performance; (b) Differentiation strategy, green product innovation, and firm performance.

Model 5 and Model 6 show the results for the influences of competitive intensity in. In Model 5, we found that for green product innovation, the positive moderating effect of differentiation strategy is enhanced by competitive intensity $(\beta=0.09, p<0.1)$. Furthermore, for green process innovation, the negative moderating effect of differentiation strategy is strengthened by competitive intensity $(\beta=-0.11, p<0.1)$. Hence, H5a and H5b are both supported. In Model 6, we found that competitive intensity enhances both the negative moderating effect of cost-leadership strategy on the green product innovation-firm performance linkage $(\beta=-0.24, p<0.01)$, and the positive moderating effect on green process innovation-firm performance linkage $(\beta=0.18, p<0.05)$. Therefore, H6a and H6b are also supported.

We further plotted the three-way interaction effects of green innovation, competitive strategy, and competitive intensity in Figures 4 and 5 and ran some simple slope tests in Table 5. The relationship between green product innovation and firm performance is most positive when differentiation strategy and competitive intensity are both high $(\beta=0.64, p<0.05)$. The relationship between green process innovation and firm performance is most positive when differentiation strategy is low and competitive intensity is high $(\beta=0.68, p<0.05)$. These suggest that when competition is intense, high differentiation strategy is more suitable for firms to enhance performance through green product innovation but not through green process innovation, providing further support for $\mathrm{H} 5 \mathrm{a}$ and $\mathrm{H} 5 \mathrm{~b}$. The relationship between green product innovation and firm performance is most positive when cost-leadership strategy 
is low and competitive intensity is high $(\beta=0.94, p<0.01)$. The relationship between green process innovation and firm performance is most positive when cost-leadership strategy and competitive intensity are both high $(\beta=0.87, p<0.01)$. These suggest that when competition is intense, high cost-leadership strategy is more suitable for firms to enhance performance through green process innovation, but not through green product innovation, providing further support for H6a and H6b. Figure 6 summarizes the results of our models.

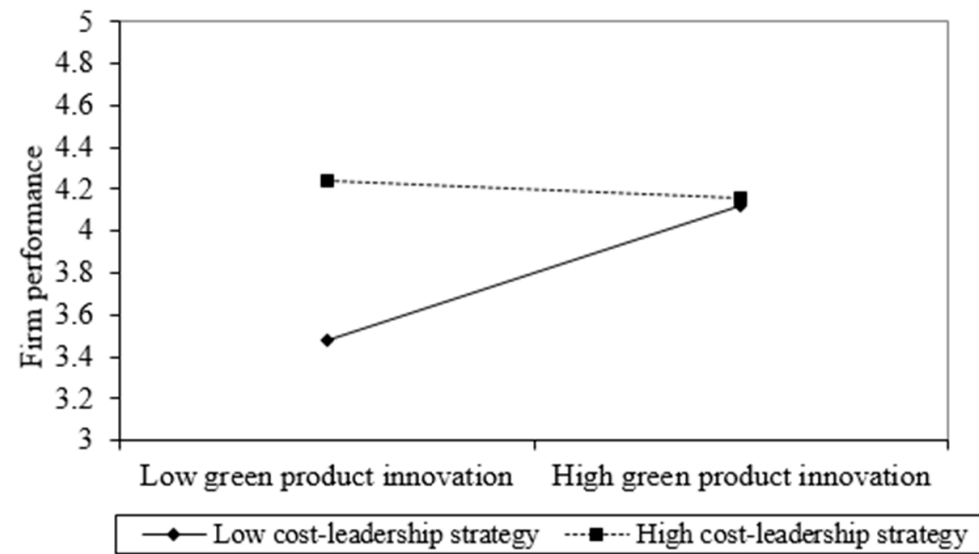

(a)

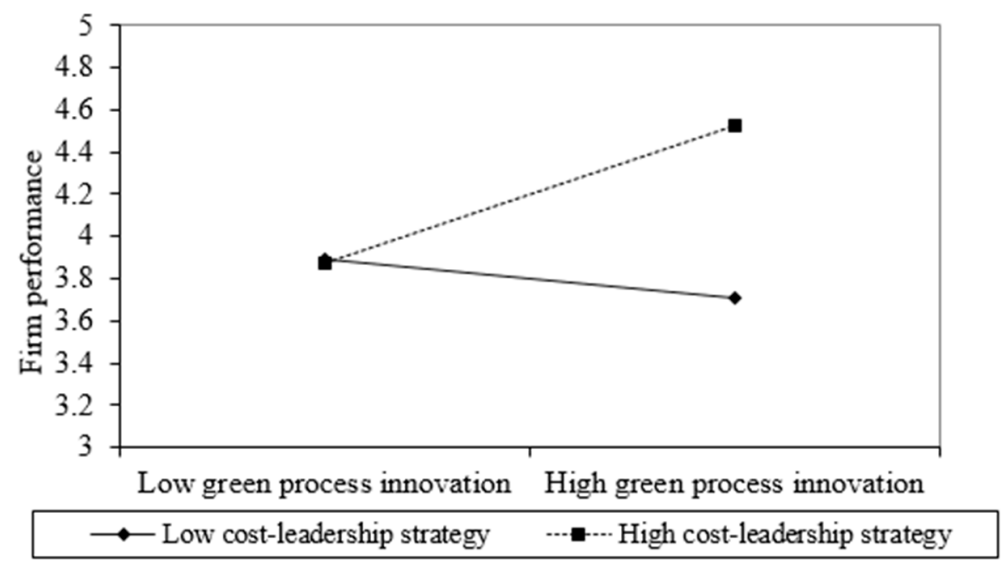

(b)

Figure 3. (a) Cost-leadership strategy, green product innovation, and firm performance; (b) Cost-leadership strategy, green product innovation, and firm performance.

Table 5. Results of simple slope tests.

\begin{tabular}{lcc}
\hline Dependent Variable & \multicolumn{2}{c}{ Firm Performance } \\
\hline Independent Variables & $\begin{array}{c}\text { Green Product } \\
\text { Innovation }\end{array}$ & $\begin{array}{c}\text { Green Process } \\
\text { Innovation }\end{array}$ \\
\hline High differentiation strategy, High competitive intensity & $0.64^{* *}$ & -0.05 \\
High differentiation strategy, Low competitive intensity & 0.03 & -0.14 \\
Low differentiation strategy, High competitive intensity & 0.06 & $0.68^{* *}$ \\
Low differentiation strategy, Low competitive intensity & -0.11 & 0.07 \\
High cost-leadership strategy, High competitive intensity & -0.14 & $0.87^{* * *}$ \\
High cost-leadership strategy, Low competitive intensity & 0.01 & 0.01 \\
Low cost-leadership strategy, High competitive intensity & $0.94^{* * *}$ & -0.15 \\
Low cost-leadership strategy, Low competitive intensity & -0.11 & -0.12 \\
\hline
\end{tabular}

${ }^{* *} p<0.05 ;{ }^{* * *} p<0.01$. 


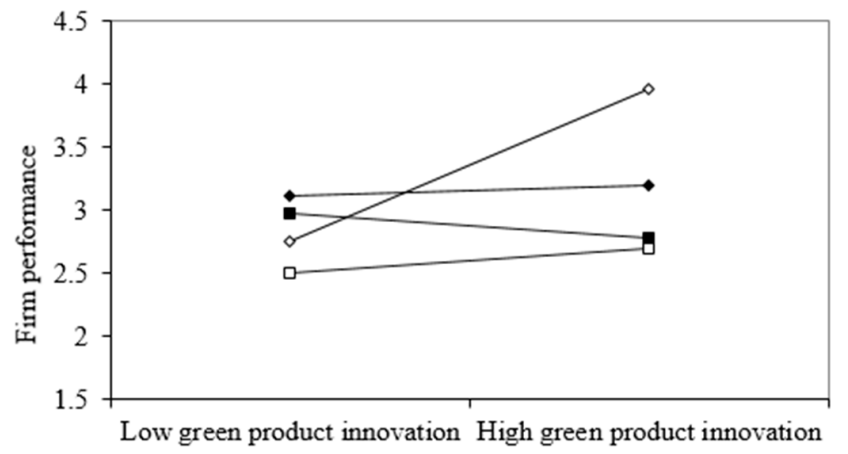

$\neg$ (1) High differentiation strategy, High competitive intensity $\rightarrow-$ (2) High differentiation strategy, Low competitive intensity

$\rightarrow-$ (3) Low differentiation strategy, High competitive intensity

$\rightarrow-$ (4) Low differentiation strategy, Low competitive intensity

\section{(a)}

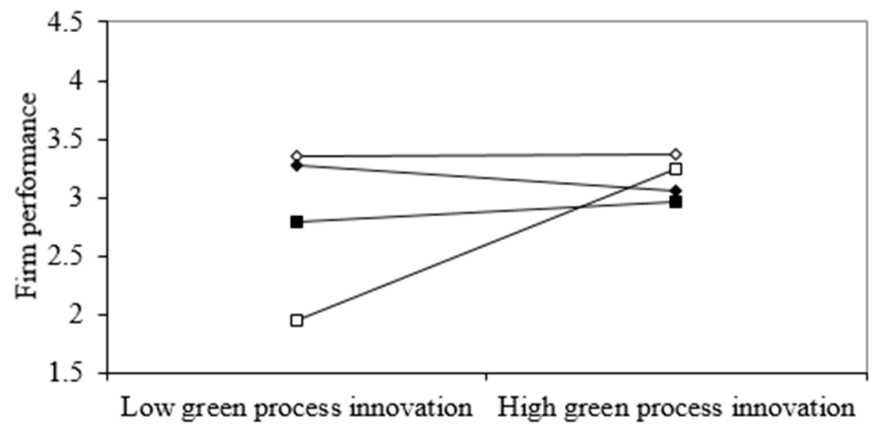

$\multimap-(1)$ High differentiation strategy, High competitive intensity

- (2) High differentiation strategy, Low competitive intensity

-(3) Low differentiation strategy, High competitive intensity

(4) Low differentiation strategy, Low competitive intensity

(b)

Figure 4. (a) Competitive intensity and the moderation of differentiation strategy (green product innovation); (b) Competitive intensity and the moderation of differentiation strategy (green process innovation).

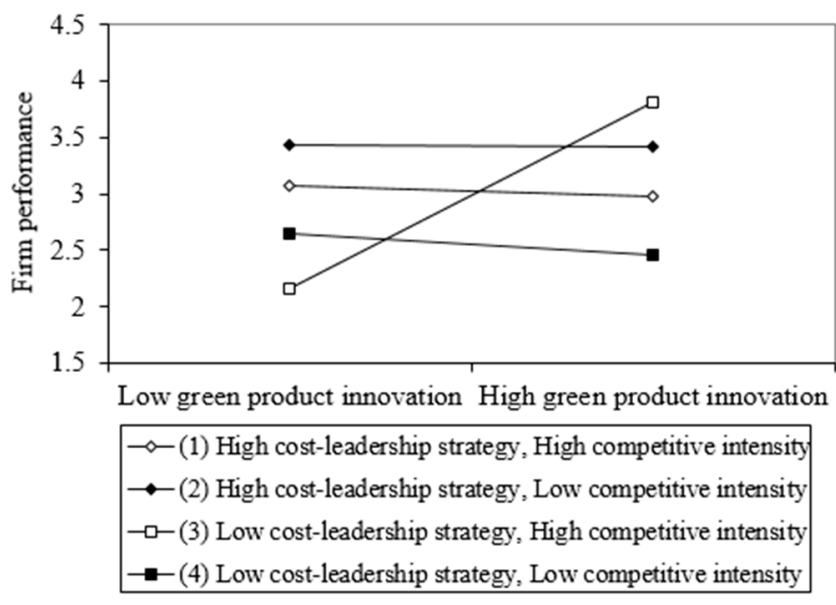

(a)

Figure 5. Cont. 


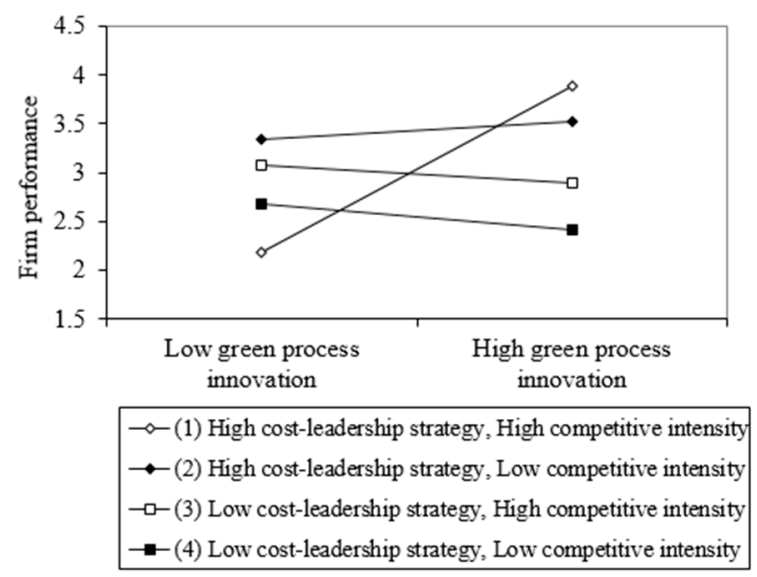

(b)

Figure 5. (a) Competitive intensity and the moderation of differentiation strategy (green product innovation); (b) Competitive intensity and the moderation of differentiation strategy (green process innovation).

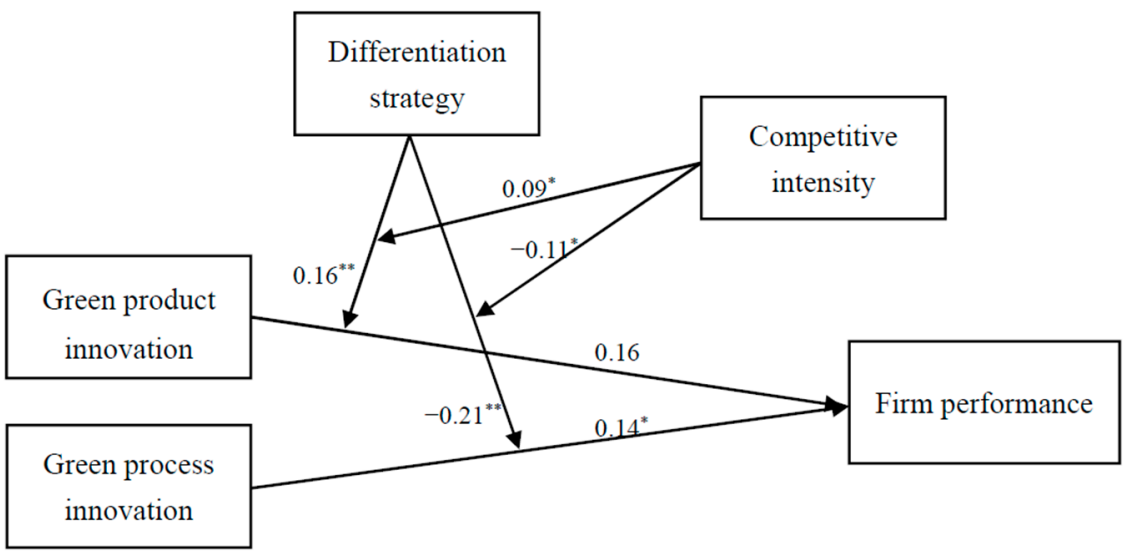

(a)

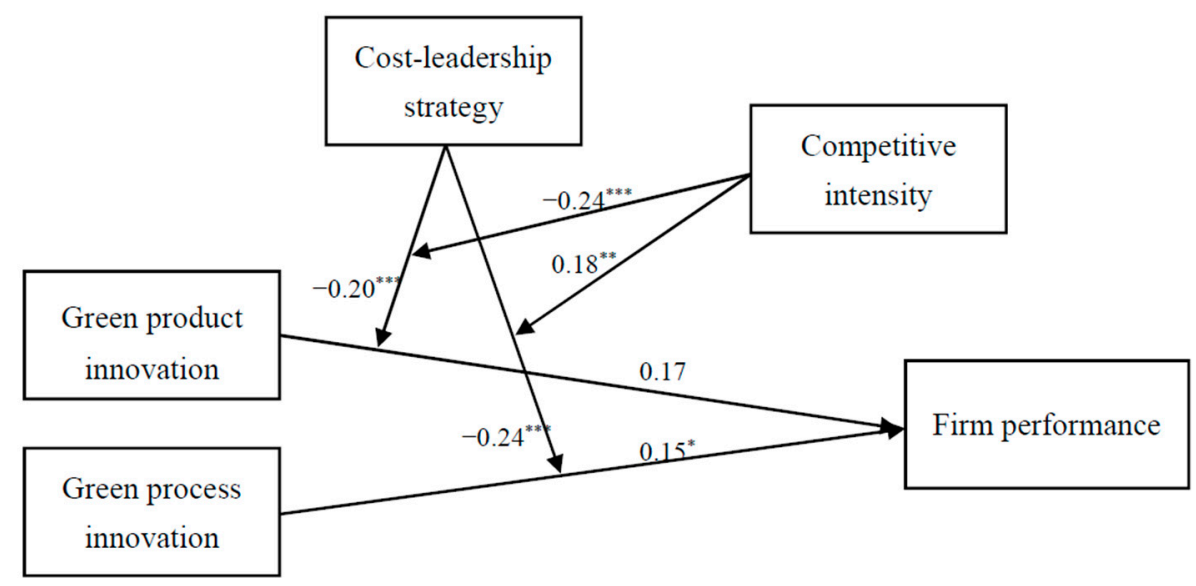

(b)

Figure 6. (a) Moderating effect of differentiation strategy; (b) Moderating effect of differentiation strategy. ${ }^{*} p<0.1 ;{ }^{* *} p<0.05 ;{ }^{* * *} p<0.01$. 


\section{Discussion}

\subsection{Theoretical contributions}

This study's findings contribute to the extant literature on green innovation and competitive strategy. First, by investigating the moderation of competitive strategy, our research enriches current understanding of the performance implications of green innovation. Previous studies have provided diverse arguments and mixed findings for the relationship between green innovation and firm performance. While some scholars suggest green innovation enhances firm performance by attracting more social support from firms' stakeholders [32,33], others argue that green innovation is often decoupled from firm competitiveness since it may be a mere response to stakeholders' nonmarket claims $[9,36]$. To disentangle the complex relationship between green innovation and firm performance, an examination on the moderating effects not only helps to delineate the conditions in which green innovation serves as means of value creation, but also to clarify different theoretical arguments in the extant literature.

Consistent with the positive view such as Chang [11], Ge et al. [34] and Przychodzen and Przychodzen [87], our results show that green innovation improves firm performance. More importantly, we find a positive moderation by differentiation strategy on the relationship between green product innovation and firm performance, but a negative moderation on the relationship between green process innovation and firm performance. In addition, cost-leadership strategy negatively moderates the relationship green product innovation-firm performance, and positively moderates the linkage green process innovation-firm performance. These findings indicate that the performance-enhancing effect of specific type of green innovation is contingent on competitive strategy. It provides a plausible explanation for the contradictory empirical conclusions reached by previous researchers on the performance consequence of green innovation. Moreover, our study also highlights value capturing from green innovation, and emphasizes the importance of matching green innovation with business strategy in gaining competitiveness in the market.

Second, we believe we have advanced the research on competitive strategy by elaborating its value in green management. Previous studies have shown that competitive strategy facilitates firms' organizational learning [88] and entrepreneurial activities [57]. To provide a more in-depth understanding of green management, scholars have called for research aimed at further clarifying the role of competitive strategy in fulfilling economic goals and environmental responsibility simultaneously $[24,25]$. The findings of the present study suggest that differentiation strategy and cost-leadership strategy have different moderating effects on green innovation-firm performance associations, and their moderating effects will be stronger as competitive intensity increases. This implies that competitive strategy is critical in realizing the performance implications of green innovation, especially when competition is intense [89]. Beyond the direct performance benefits [21], competitive strategy can influence firm performance through its value-capturing role in capitalizing on and profit from green innovation. Therefore, this study responds to the call for a more nuanced understanding of competitive strategy, highlights the importance of competitive strategy in green management, and enhances theoretical perspectives on the implications of competitive strategy.

\subsection{Managerial Implications}

The implications of this study offer managers three valuable tools to effectively manage green innovation under competition. First, the findings suggest that differentiation has a positive moderating effect on performance consequence of green product innovation, and such effects will be stronger as competitive intensity increases. Accordingly, market differentiators should focus on integrating environmentalism into product innovation, especially when facing fierce competition. Second, a cost-leadership strategy help firms to derive profits from green process innovation, and such role will be more salient in situations of high competition intensity. Firms aiming to obtain a cost-leader position should make more effort to upgrade their manufacturing process with advanced green technology, 
so that they can establish and then maintain their efficiency advantage. Third, the mismatch between green innovation and competitive strategy will reduce the potential competitiveness to be derived from green innovation. Hence, managers should be cautious about the potential tensions between differentiation strategy and green process innovation, and between cost-leadership strategy and green product innovation. To maximize the performance implications of green innovation, firms may need to align green innovation activities with particular competitive strategies.

\subsection{Limitations and Future Directions}

Several limitations are noteworthy, which also suggest avenues for future research. First, this study did not explicitly examine the value-capturing mechanism of business strategy. Though it was beyond the scope of our study, future studies could develop mediation models or use case studies to further elaborate the processes through which green innovation and competitive strategy affect firms' competitiveness in the market. Second, the findings of this study are based on a Chinese context. The differences between China and other countries should be carefully considered. Thus, it would be interesting to explore whether and how our findings can be generalized to other contexts and take into account some national factors. Third, while our cross-sector survey is appropriate for a theoretical model with strong implications, longitudinal studies are still needed. Future research can use longitudinal designs to capture the casual relationships and improve the effectiveness of the theoretical framework used in this study.

Author Contributions: Jiawen Chen proposed the conceptualization of this study. Linlin Liu made the formal analysis and wrote the paper.

Funding: This research was funded by the China Postdoctoral Science Foundation (2018M643380).

Conflicts of Interest: The authors declare no conflict of interest.

\section{Appendix A}

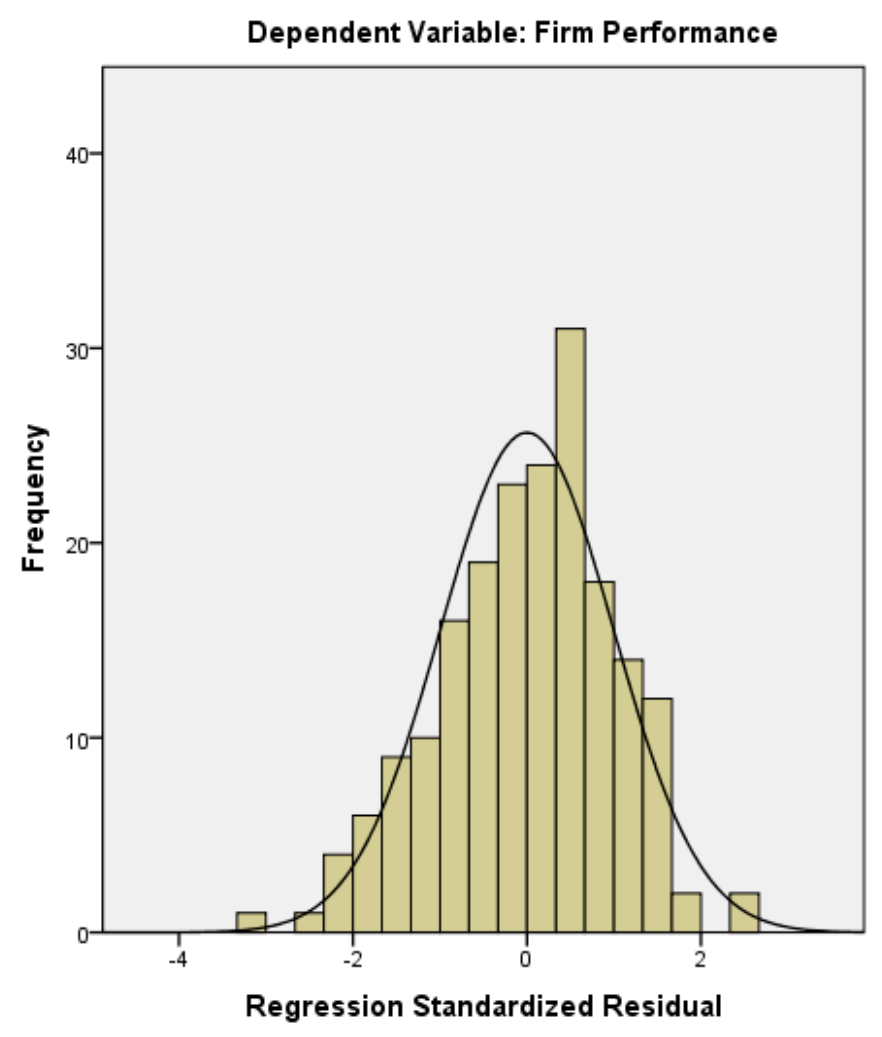

Figure A1. Histogram of regression standardized residual. 


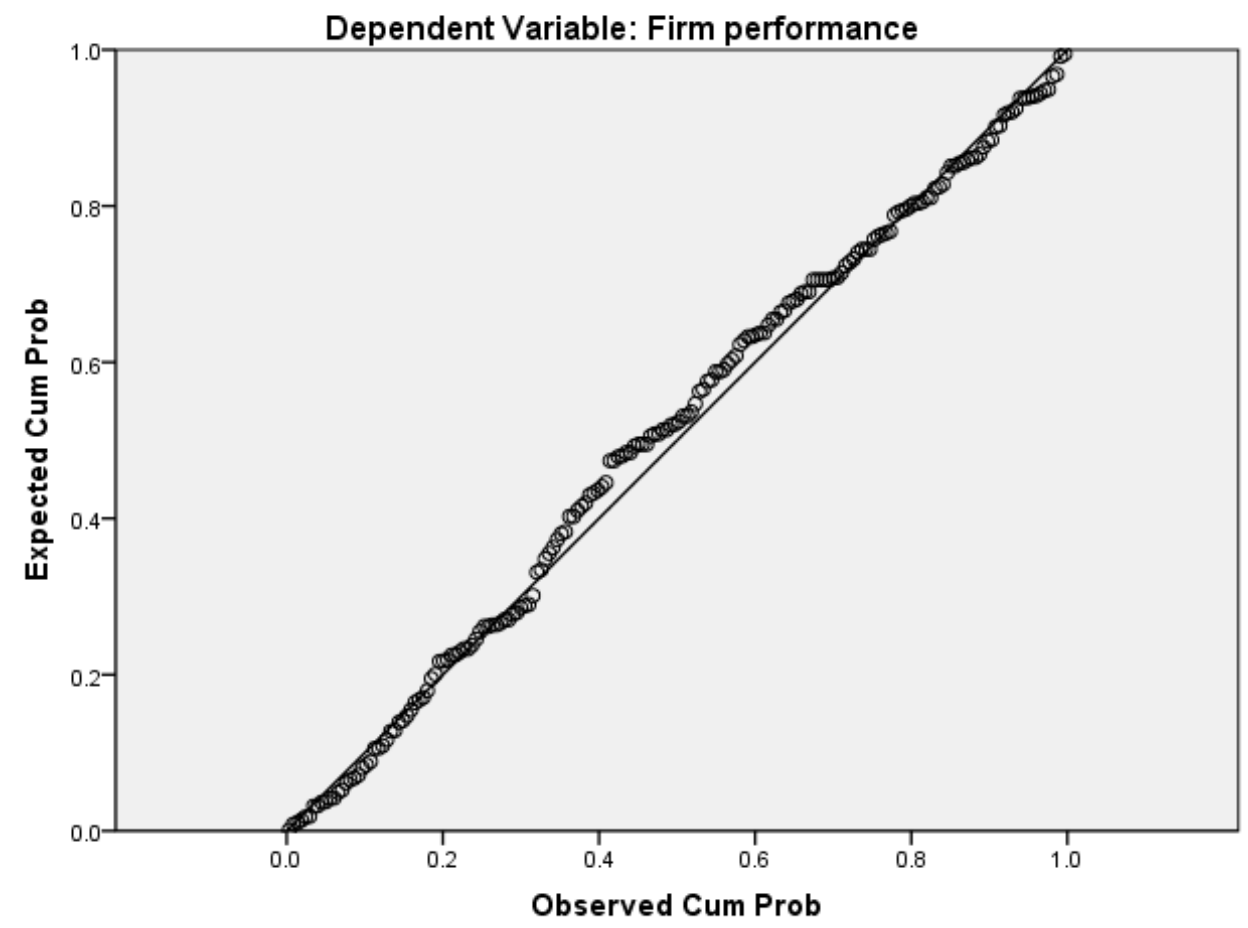

Figure A2. Normal P-P plot.

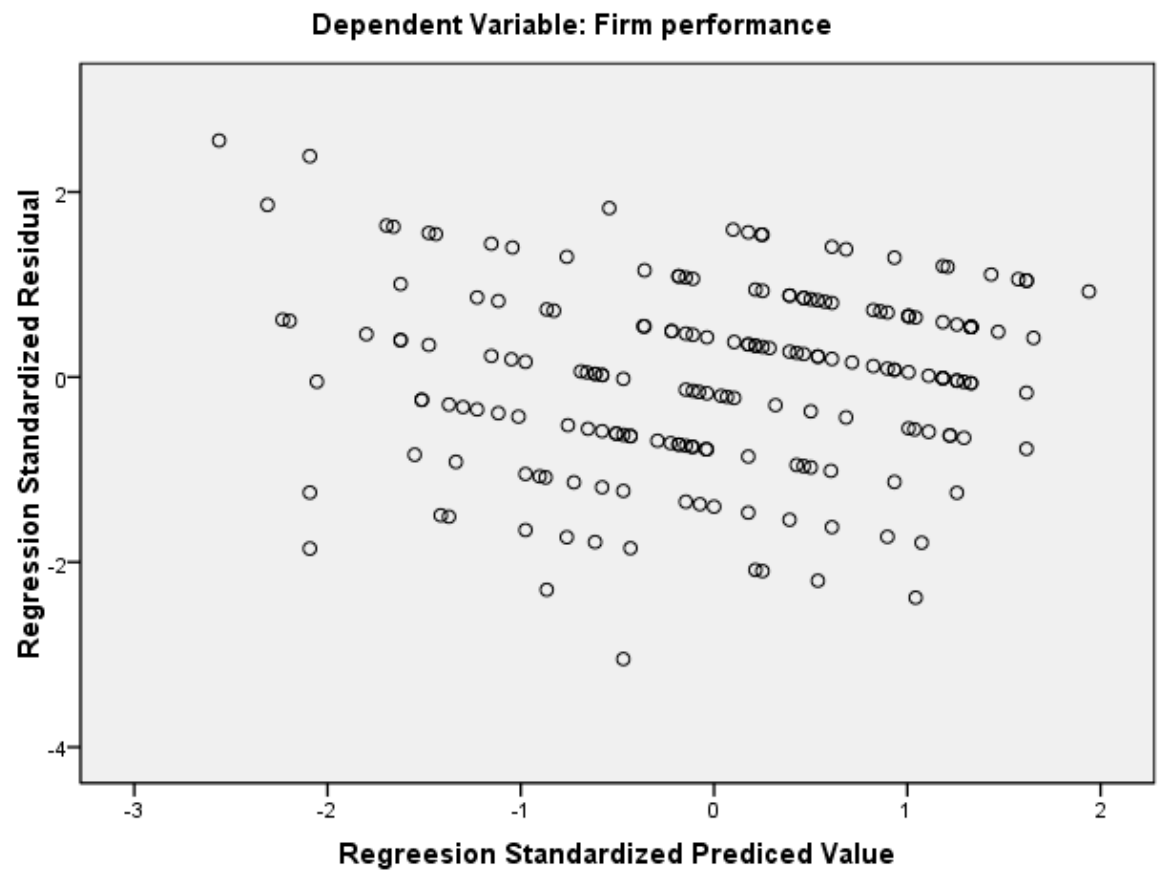

Figure A3. Scatter plot between residuals and predicted firm performance.

\section{References}

1. Chen, Y.; Lai, S.; Wen, C. The influence of green innovation performance on corporate advantage in Taiwan. J. Bus. Ethics 2006, 67, 331-339. [CrossRef]

2. Richard, A.; Sally, J.; John, B.; David, D.; Patrick, O. Sustainability-oriented innovation: A systematic review. Int. J. Manag. Rev. 2016, 18, 180-205.

3. Chang, C.H.; Sam, A.G. Corporate environmentalism and environmental innovation. J. Environ. Manag. 2015, 153, 84-92. [CrossRef] 
4. Cai, W.; Zhou, X. On the drivers of eco-innovation: Empirical evidence from China. J. Clean. Prod. 2014, 79, 239-248. [CrossRef]

5. Lin, H.; Zeng, S.X.; Ma, H.Y.; Qi, G.Y.; Tam, V.W. Can political capital drive corporate green innovation? Lessons from China. J. Clean. Prod. 2014, 64, 63-72. [CrossRef]

6. Shaked, A.; Sutton, J. Relaxing price competition through product differentiation. Rev. Econ. Stud. 1982, 49, 3-13. [CrossRef]

7. Bonanno, G.; Haworth, B. Intensity of competition and the choice between product and process innovation. Int. J. Ind. Organ. 1998, 16, 495-510. [CrossRef]

8. Czarnitzki, D.; Etro, F.; Kraft, K. Endogenous market structures and innovation by leaders: An empirical test. Economica 2014, 81, 117-139. [CrossRef]

9. Huang, J.; Li, Y. Green innovation and performance: The view of organizational capability and social reciprocity. J. Bus. Ethics 2017, 145, 309-324. [CrossRef]

10. Dangelico, R.M. Green product innovation: Where we are and where we are going. Bus. Strategy Environ. 2016, 25, 560-576. [CrossRef]

11. Chang, $C$. The influence of corporate environmental ethics on competitive advantage: The mediation role of green innovation. J. Bus. Ethics 2011, 104, 361-370. [CrossRef]

12. Liu, X.; Dai, H.; Cheng, P. Drivers of integrated environmental innovation and impact on company competitiveness: Evidence from 18 Chinese firms. Int. J. Technol. Glob. 2011, 5, 255-280. [CrossRef]

13. Aguilera-Caracuel, J.; Ortiz-de-Mandojana, N. Green innovation and financial performance: An institutional approach. Organ. Environ. 2013, 26, 365-385. [CrossRef]

14. Ginsberg, J.M.; Bloom, P.N. Choosing the right green-marketing strategy. MIT Sloan Manag. Rev. 2004, 46, 79-84.

15. McWilliams, A.; Siegel, D.S. Creating and capturing value: Strategic corporate social responsibility, resource-based theory, and sustainable competitive advantage. J. Manag. 2011, 37, 1480-1495. [CrossRef]

16. Teece, D.J. Business models, business strategy and innovation. Long Range Plan. 2010, 43, 172-194. [CrossRef]

17. James, S.D.; Leiblein, M.J.; Lu, S. How firms capture value from their innovations. J. Manag. 2013, 39, 1123-1155.

18. Porter, M.E. Competitive Advantage: Creating and Sustaining Superior Performance; Free Press: New York, NY, USA, 1985.

19. Li, C.B.; Li, J. Achieving superior financial performance in China: Differentiation, cost leadership, or both? J. Int. Mark. 2008, 16, 1-22. [CrossRef]

20. Dangelico, R.M.; Pujari, D. Mainstreaming green product innovation: Why and how companies integrate environmental sustainability. J. Bus. Ethics 2010, 95, 471-486. [CrossRef]

21. Chan, R.Y.; He, H.; Chan, H.K.; Wang, W.Y. Environmental orientation and corporate performance: The mediation mechanism of green supply chain management and moderating effect of competitive intensity. Ind. Mark. Manag. 2012, 41, 621-630. [CrossRef]

22. Leonidou, L.C.; Christodoulides, P.; Kyrgidou, L.P.; Palihawadana, D. Internal drivers and performance consequences of small firm green business strategy: The moderating role of external forces. J. Bus. Ethics 2017, 140, 585-606. [CrossRef]

23. Orsato, R.J. Competitive Environmental Strategies: When Does it Pay to Be Green? Calif. Manag. Rev. 2006, 48, 127-143. [CrossRef]

24. De Medeiros, J.F.; Vidor, G.; Ribeiro, J. Driving factors for the success of the green innovation market: A relationship system proposal. J. Bus. Ethics 2018, 147, 327-341. [CrossRef]

25. Carton, R.B.; Hofer, C.W. Measuring Organizational Performance: Metrics for Entrepreneurship and Strategic Management Research; Edward Elgar Publishing: Cheltenham, UK, 2006.

26. Lepak, D.P.; Smith, K.G.; Taylor, M.S. Value creation and value capture: A multilevel perspective. Acad. Manag. Rev. 2007, 32, 180-194. [CrossRef]

27. Hitt, M.A.; Ireland, R.D. Corporate distinctive competence, strategy, industry and performance. Strateg. Manag. J. 1985, 6, 273-293. [CrossRef]

28. Hawawini, G.; Subramanian, V.; Verdin, P. Is performance driven by industry-or firm-specific factors? A new look at the evidence. Strateg. Manag. J. 2003, 24, 1-16. [CrossRef]

29. Mellahi, K.; Frynas, J.G.; Sun, P.; Siegel, D. A review of the nonmarket strategy literature: Toward a multi-theoretical integration. J. Manag. 2016, 42, 143-173. [CrossRef] 
30. Chen, Y. The driver of green innovation and green image-Green core competence. J. Bus. Ethics 2008, 81, 531-543. [CrossRef]

31. Seebode, D.; Jeanrenaud, S.; Bessant, J. Managing innovation for sustainability. RED Manag. 2012, 42, 195-206.

32. Zhang, Y.; Sun, J.; Yang, Z.; Li, S. Organizational learning and Green innovation: Does Environmental proactivity matter? Sustainability 2018, 10, 3737. [CrossRef]

33. Chiou, T.; Chan, H.K.; Lettice, F.; Chung, S.H. The influence of greening the suppliers and green innovation on environmental performance and competitive advantage in Taiwan. Transp. Res. E-Logist. Transp. Rev. 2011, 47, 822-836. [CrossRef]

34. Ge, B.; Yang, Y.; Jiang, D.; Gao, Y.; Du, X.; Zhou, T. An empirical study on green innovation strategy and sustainable competitive advantage: Path and boundary. Sustainability 2018, 10, 3631. [CrossRef]

35. Leenders, M.; Chandra, Y. Antecedents and consequences of green innovation in the wine industry: The role of channel structure. Technol. Anal. Strat. Manag. 2013, 25, 203-218. [CrossRef]

36. Ghisetti, C.; Rennings, K. Environmental innovations and profitability: How does it pay to be green? An empirical analysis on the German innovation survey. J. Clean. Prod. 2014, 75, 106-117. [CrossRef]

37. Chen, Y.; Chang, K. The nonlinear effect of green innovation on the corporate competitive advantage. Qual. Quant. 2013, 47, 271-286. [CrossRef]

38. Chan, H.K.; Yee, R.W.; Dai, J.; Lim, M.K. The moderating effect of environmental dynamism on green product innovation and performance. Int. J. Prod. Econ. 2016, 181, 384-391. [CrossRef]

39. Martinez-del-Rio, J.; Antolin-Lopez, R.; Cespedes-Lorente, J.J. Being green against the wind? The moderating effect of munificence on acquiring environmental competitive advantages. Organ. Environ. 2015, 28, 181-203. [CrossRef]

40. Leonidou, L.C.; Katsikeas, C.S.; Fotiadis, T.A.; Christodoulides, P. Antecedents and consequences of an eco-friendly export marketing strategy: The moderating role of foreign public concern and competitive intensity. J. Int. Mark. 2013, 21, 22-46. [CrossRef]

41. Hitt, M.A.; Ireland, R.D.; Sirmon, D.G.; Trahms, C.A. Strategic entrepreneurship: Creating value for individuals, organizations, and society. Acad. Manag. Perspect. 2011, 25, 57-75.

42. Hitt, M.A.; Tyler, B.B. Strategic decision models: Integrating different perspectives. Strat. Manag. J. 1991, 12, 327-351. [CrossRef]

43. Miller, D. Relating Porter's business strategies to environment and structure: Analysis and performance implications. Acad. Manag. J. 1988, 31, 280-308.

44. Frambach, R.T.; Prabhu, J.; Verhallen, T.M. The influence of business strategy on new product activity: The role of market orientation. Int. J. Res. Mark. 2003, 20, 377-397. [CrossRef]

45. Beath, J.; Katsoulacos, Y. The Economic Theory of Product Differentiation; Cambridge University Press: Cambridge, UK, 1991.

46. Matthew, B.M.; Harvey, M.L. The value of pricing control in export channels: A governance perspective. J. Int. Mark. 2001, 9, 1-29.

47. Zott, C.; Amit, R. The fit between product market strategy and business model: Implications for firm performance. Strat. Manag. J. 2008, 29, 1-26. [CrossRef]

48. Song, X.M.; Parry, M.E. A cross-national comparative study of new product development processes: Japan and the United States. J. Mark. 1997, 61,1-18. [CrossRef]

49. Ward, P.T.; Bickford, D.J.; Leong, G.K. Configurations of manufacturing strategy, business Strategy, environment and structure. J. Manag. 1996, 22, 597-626. [CrossRef]

50. Aulakh, P.S.; Rotate, M.; Teegen, H. Export strategies and performance of firms from emerging economies: Evidence from Brazil, Chile, and Mexico. Acad. Manag. J. 2000, 43, 342-361.

51. Block, J.H.; Kohn, K.; Miller, D.; Ullrich, K. Necessity entrepreneurship and competitive strategy. Small Bus. Econ. 2015, 44, 37-54. [CrossRef]

52. Richard, O.C. Racial diversity, business strategy, and firm performance: A resource-based view. Acad. Manag. J. 2000, 43, 164-177.

53. Neal, A.; West, M.A.; Patterson, M.G. Do organizational climate and competitive strategy moderate the relationship between human resource management and productivity? J. Manag. 2005, 31, 492-512. [CrossRef]

54. Jänicke, M. Ecological modernization: New perspectives. J. Clean. Prod. 2008, 16, 557-565. [CrossRef] 
55. Zhu, Q.; Sarkis, J.; Lai, K. Green supply chain management innovation diffusion and its relationship to organizational improvement: An ecological modernization perspective. J. Eng. Technol. Manag. 2012, 29, 168-185. [CrossRef]

56. Qi, G.; Zeng, S.; Tam, C.; Yin, H.; Zou, H. Stakeholders' influences on corporate green innovation strategy: A case study of manufacturing firms in China. Corp. Soc. Responsib. Environ. Manag. 2013, 20, 1-14.

57. Verreynne, M.; Meyer, D. Small business strategy and the industry life cycle. Small Bus. Econ. 2010, 35, 399-416. [CrossRef]

58. Augusto, M.; Coelho, F. Market orientation and new-to-the-world products: Exploring the moderating effects of innovativeness, competitive strength, and environmental forces. Ind. Mark. Manag. 2009, 38, 94-108. [CrossRef]

59. Boehe, D.M.; Barin, C.L. Corporate social responsibility, product differentiation strategy and export performance. J. Bus. Ethics 2010, 91, 325-346. [CrossRef]

60. Prajogo, D.I. The strategic fit between innovation strategies and business environment in delivering business performance. Int. J. Prod. Econ. 2016, 171, 241-249. [CrossRef]

61. Michaud, C.; Llerena, D. Green consumer behaviour: An experimental analysis of willingness to pay for remanufactured products. Bus. Strategy Environ. 2011, 20, 408-420. [CrossRef]

62. Katila, R.; Ahuja, G. Something old, something new: A longitudinal study of search behavior and new product introduction. Acad. Manag. J. 2002, 45, 1183-1194.

63. Hart, S.L.; Ahuja, G. Does it pay to be green? An empirical examination of the relationship between emission reduction and firm performance. Bus. Strategy Environ. 1996, 5, 30-37. [CrossRef]

64. Schuhwerk, M.E.; Lefkoff-Hagius, R. Green or non-green? Does type of appeal matter when advertising a green product? J. Advert. 1995, 24, 45-54. [CrossRef]

65. Danaher, P.J.; Hardie, B.; Putsis, P. Marketing-mix variables and the diffusion of successive generations of a technological innovation. J. Mark. Res. 2001, 38, 501-514. [CrossRef]

66. Tseng, M.; Wang, R.; Chiu, A.S.; Geng, Y.; Lin, Y.H. Improving performance of green innovation practices under uncertainty. J. Clean. Prod. 2013, 40, 71-82. [CrossRef]

67. Casadesus-Masanell, R.; Ricart, J.E. From strategy to business models and onto tactics. Long Range Plan. 2010, 43, 195-215. [CrossRef]

68. Kogut, B.; Zander, U. Knowledge of the firm, combinative capabilities, and the replication of technology. Organ. Sci. 1992, 3, 383-397. [CrossRef]

69. Rusinko, C. Green manufacturing: An evaluation of environmentally sustainable manufacturing practices and their impact on competitive outcomes. IEEE Trans. Eng. Manag. 2007, 54, 445-454. [CrossRef]

70. Rothenberg, S.; Pil, F.K.; Maxwell, J. Lean, green, and the quest for superior environmental performance. Prod. Oper. Manag. 2001, 10, 228-243. [CrossRef]

71. Amit, R. Cost leadership strategy and experience curves. Strat. Manag. J. 1986, 7, 281-292. [CrossRef]

72. Nie, W.; Abler, D.; Zhu, L.; Li, T.; Lin, G. Consumer Preferences and Welfare Evaluation under Current Food Inspection Measures in China: Evidence from Real Experiment Choice of Rice Labels. Sustainability 2018, 10, 4003. [CrossRef]

73. Terlaak, A.; King, A.A. The effect of certification with the ISO 9000 Quality Management Standard: A signaling approach. J. Econ. Behav. Organ. 2006, 60, 579-602. [CrossRef]

74. Jaworski, B.J.; Kohli, A.K. Market orientation: Antecedents and consequences. J. Mark. 1993, 57, 53-70. [CrossRef]

75. Auh, S.; Menguc, B. Balancing exploration and exploitation: The moderating role of competitive intensity. J. Bus. Res. 2005, 58, 1652-1661. [CrossRef]

76. Olivier, C.; Peter, Z. Value creation and value capture with frictions. Strat. Manag. J. 2011, 32, 1206-1231.

77. Zhou, K.Z. Innovation, imitation, and new product performance: The case of China. Ind. Mark. Manag. 2006, 35, 394-402. [CrossRef]

78. Desyllas, P.; Miozzo, M.; Lee, H.; Mile, I. Capturing value from innovation in knowledge-intensive business service firms: The role of competitive strategy. Br. J. Manag. 2018, 29, 769-795. [CrossRef]

79. Cleff, T.; Rennings, K. Determinants of environmental product and process innovation. Environ. Policy Gov. 1999, 9, 191-201. [CrossRef]

80. Su, Z.; Guo, H.; Sun, W. Exploration and firm performance: The moderating impact of competitive strategy. Br. J. Manag. 2017, 28, 357-371. [CrossRef] 
81. Chaganti, R.; Chaganti, R.; Mahajan, V. Profitable small business strategies under different types of competition. Entrep. Theory Pract. 1989, 13, 21-36. [CrossRef]

82. Luo, Y. Environment-strategy-performance relations in small businesses in China: A case of township and village enterprises in southern China. J. Small Bus. Manag. 1999, 37, 37-52.

83. Su, Z.; Peng, J.; Shen, H.; Xiao, T. Technological capability, marketing capability, and firm performance in turbulent conditions. Manag. Organ. Rev. 2013, 9, 115-138. [CrossRef]

84. Parnell, J.; Long, Z.; Lester, D. Competitive strategy, capabilities and uncertainty in small and medium sized enterprises (SMEs) in China and the United States. Manag. Decis. 2015, 53, 402-431. [CrossRef]

85. Bowman, C.; Daniels, K. The influence of functional experience on perceptions of strategic priorities. Br. J. Manag. 1995, 6, 157-162. [CrossRef]

86. Numally, J.C. Psychometric Theory; McGraw-Hill: New York, NY, USA, 1978.

87. Przychodzen, J.; Przychodzen, W. Relationships between eco-innovation and financial performance: Evidence from publicly traded companies in Poland and Hungary. J. Clean. Prod. 2015, 90, 253-263. [CrossRef]

88. Santos-Vijande, M.L.; López-Sánchez, J.Á.; Trespalacios, J.A. How organizational learning affects a firm's flexibility, competitive strategy, and performance. J. Bus. Res. 2012, 65, 1079-1089. [CrossRef]

89. Esty, D.; Winston, A. Green to Gold: How Smart Companies Use Environmental Strategy to Innovate, Create Value, and Build Competitive Advantage; John Wiley \& Sons: Hoboken, NJ, USA, 2009.

(C) 2018 by the authors. Licensee MDPI, Basel, Switzerland. This article is an open access article distributed under the terms and conditions of the Creative Commons Attribution (CC BY) license (http://creativecommons.org/licenses/by/4.0/). 